\title{
VIRTUALAUS ASMENS VEIKLA IR PLĖTROS GALIMYBE்S
}

\author{
Vytautas Sūdžius ${ }^{1}$, Artūras Stepanovas $^{2}$ \\ Vilniaus Gedimino technikos universitetas, Sauletekio al. 11, LT-10223 Vilnius, Lietuva \\ El.paštas: ${ }^{1}$ Vytautas.Sudzius@vgtu.lt; ${ }^{2}$ Arturas.Stepanovas@vgtu.lt
}

Iteikta 2009-11-25; priimta 2010-02-22

\begin{abstract}
Santrauka. Straipsnyje išryškinami svarbiausieji virtualaus asmens bruožai ir ypatumai, bandoma numatyti jo veiklos pletros galimybes. Asmuo, kuris nuolat naudojasi informacinėmis technologijomis, sèkmingai formuoja virtualaus asmens žmogiškuosius ir kitus svarbius bruožus. Fiziniai ir juridiniai asmenys, bendraudami virtualioje erdvejje, patys suvokiami kaip virtualūs asmenys. Virtualūs asmenys gali lanksčiau ir geriau spręsti šiuolaikines socialines ir ekonomines problemas. Tradicinių ir virtualių asmenų skirtumas rinkoje - tai galimybe interaktyviai bendrauti pirkejams ir pardavejams. Virtualus asmuo neturi fizinių veikimo ribų, todèl praktiškai gali pasiekti kitus individualius ar kolektyvinius asmenis be apribojimų, daugiau dèmesio gali skirti tam tikros organizacijos vidiniams ir išoriniams ryšiams. Personalizuotas ryšių valdymas yra visiškai nauja galinga organizacijos priemonė teikiant ypatingas paslaugas kiekvienam klientui individualiai ir turi geras naudojimo perspektyvas. Virtualių asmenų žinios suteikia galimybių efektyviau naudoti išteklius ir išvengti klaidingų sprendimų.
\end{abstract}

Reikšminiai žodžiai: bruožai, interaktyvumas, plètros galimybès, virtualus asmuo, virtuali erdvè.

\section{DEVELOPMENT POSSIBILITIES OF FEATURES IN THE VIRTUAL PERSON}

\author{
Vytautas Sūdžius ${ }^{1}$, Artūras Stepanovas ${ }^{2}$ \\ Vilnius Gediminas Technical University, Sauletekio al. 11, LT-10223 Vilnius, Lithuania \\ E-mails: ${ }^{1}$ Vytautas Sudzius@vgtu.lt; ${ }^{2}$ Arturas Stepanovas@vgtu.lt \\ Received 25 November 2009; accepted 22 February 2010
}

\begin{abstract}
This paper intends to evaluate the features, peculiarities and possibilities of virtual person. A person, who constantly uses social-economic information, creates human and other features of virtual person. Individuals and companies communicating in virtual space are conceivable as virtual person. The virtual person can be more flexible, better adapted to new external environment oriented to new facilities and can better avoid menaces. The biggest difference of virtual persons from traditional individual is possibility interactively communicate with members in the market, seller and buyer. Because virtual person has no walls and, practically, everyone can access other individuals or companies without restriction, they must pay big attention to be used inside and internationally. Personalisation of relationship is quite a new but very powerful tool of the companies and implementation of particular services for every customer has a very great future. The knowledge of imperatives of virtual person let us avoid rough mistakes and better use its possibilities.
\end{abstract}

Keywords: features, implement possibilities, interaction, virtual person, virtual space. 


\section{Ivadas}

Didèjančios interneto galimybès ir telekomunikacinès paslaugos daro dideli poveikị informacinès visuomenès formavimuisi. Pramogų, produktų ir finansinių paslaugu teikimas elektroniniu būdu, galimybè mokytis nuotoliniu būdu bei dirbti paskatino ir virtualaus asmens idejos atsiradimą ir plètrą. Informacinejje visuomenèje išskirtinę reikšmę igyja žinios ir kompetencija. Svarbus ịrankis šiai kompetencijai didinti yra informacinès ir telekomunikacijų technologijos, kurios leidžia greitai ir patogiai pasiekti ivvairius informacijos šaltinius, organizuoti tiek su darbo, tiek su asmeninėmis reikmėmis susijusią veiklą.

Nagrinejjama problema: skirtinga virtualių asmenu tarpusavio sąveika ir bendravimo su aplinka ypatumai. Materializuoti fiziniai ryšiai igauna visai kitas išraiškos formas ir priemones, suteikiančias naujų saviraiškos ir veiklos galimybių.

Tyrimo objektas - dinamiški virtualių asmenų, nepriklausomai nuo jų statuso, buvimo vietos, tikslo ir kitu ypatumų, veiklos plètros procesai, atveriantys vis nauju galimybių.

Tyrimo tikslas - įvertinti virtualių asmenų veiklos galimybes ir perspektyvas.

Tyrimo metodas - ìvairių šaltinių (Markevičius 2005; Markovic 2008; Paliulis et al. 2007; Saabeel et al. 2005; Turban et al. 2006; Vengrienè 2006 ir kt.) lyginamoji analizè.

\section{Virtualaus asmens bendrieji bruožai}

Virtualiu asmeniu gali būti asmenys ar institucijos, bendraujančios virtualioje erdveje (privatūs asmenys, visuomenès, socialinių grupių ir kt. atstovai, paslaugų teikejjai, tarpininkai, vartotojai, administruojančios ir kitos įstaigos). Virtualus asmuo turi visų valdymo sistemai būdingų ypatumų: ịvairaus tipo ir paskirties virtualiųjų objektų, ryšių ir jų palaikymo bei valdymo priemonių, bendravimo ir paslaugų teikimo procesų. Tačiau svarbiausieji sistemos nariai - dalyviai vienu metu gali būti valdymo struktūros elementu, o jau kitu atveju - išorinès aplinkos dalimi ar tam tikru rinkos segmentu (Turban et al. 2006).

Plètojant informacinę visuomenę, nuolatos didèja kompetentingų informacijos technologijų ir paslaugų specialistų bei konsultantų poreikis. Investuojant ị infrastruktūros atnaujinimą ar plètrą, būtina kartu tobulinti ir specialistu informacinius bei technologinius igūdžius, kad sukurtos sistemos ir tinklai būtų efektyviai naudojami.

Virtualaus asmens prièmimas ir suvokimas labai priklauso nuo jo aktyvumo, elgesio ir santykių visuomeneje ar tam tikroje rinkoje, nuo veiklos viešumo, vaizdumo ir akivaizdumo (Sodžiutè, Sūdžius 2006). Apie asmens veiklą dažnai sprendžiama iš darbo su klientais ir viešo pasirodymo visuomenejje. Civilizuotoje visuomenèje moralès normos igauna ypatingą atspalvị, pagal tai, kaip jų laikomasi, vertinamas ne tik pats asmuo, bet ir jo veikla teikiant bet kokią paslaugą.

Itin svarbios yra telekomunikacinès priemonès (Saabeel et al. 2005), susiejančios virtualius asmenis ir paslaugų teikèjus bei jų tarpininkus. Kadangi telekomunikacines paslaugas teikia tiesiogiai ne darbuotojai, o tam tikros informacinès priemonès, ypač didelę reikšmę igyja ne tik jų kokybiškas pateikimas klientui laiku, bet ir prieinamumas, patikimumas bei naudojimo paprastumas. Informacinès priemonès kartu atlieka ir rinkodaros funkciją, parduodamos ne tik konkrečią paslaugą, bet ir tuo pat matu formuodamos savo įvaizdị, siūlydamos naudotis ir kitomis paslaugomis. Kita vertus, paslauga turi būti projektuojama atsižvelgiant i virtualaus asmens misiją, strategiją, išteklius, ì tokius aplinkos veiksnius, kaip teisiniai aktai, valstybès bei kitų institucijų taikomą reguliavimo praktiką, ịpročius ir tradicijas (Vengrienè 2006).

Virtualus objektas turi pasižymėti savo (Cvilikas et al. 2007; Korsakienè et al. 2006; Markovic 2008; Saabeel et al. 2005; Stankevičienè, Dudènienè 2008 ir kt.):

- atitiktimi fizinio asmens charakterio bruožams;

- vientisumo ir bendravimo suderinimo ypatumais: buvimu visur, bet kur ir bet kada, kai tik prireikia derinti interesus;

- aktyvumu ir suinterisuotumu savo veikla;

- aiškiai apibrèžtu fizinio panašumo lygiu;

- personalizavimo galimybe, lengvai prisitaikant prie specifinių asmeninių kliento poreikių ar grupinių interesų;

- originalumu - ịvaizdis turi būti lengvai atpažįstamas ir įsimenamas;

- plastiškumu - savo išraiškos priemonèmis turi būti nekintamai atpažǐstamas, bet kartu gali modifikuotis, reaguojant $\underset{i}{i}$ kintančius ekonominius ir psichologinius reikalavimus, madas, socialines sąlygas;

- suderintais valdymo stiliais ir priemonėmis bei tikslingumu - turi turèti tikslinę auditoriją, pritraukti tam tikrus visuomenès narius, socialines grupes, rinkos segmentus;

- glaudžiais visuomenès, bendrijos ar organizacijos tarpusavio santykiais;

- neapibrèžtumu - palikti vietos tarp pageidaujamo ir realaus reiškinio vaizduotei, jausmams ir fantazijai;

- neutralumu. Neišskiriamas nè vienas klientas, partneris ar kitas rinkos dalyvis. Virtualus asmuo tuo yra patrauklus, nes visi jam yra lygūs ir svarbūs. Šis principas gali būti pasiektas bendrais visuomenès narių interesais ar rinkos dalyvių suteikiama nauda, kurią jie gauna ar tikisi gauti iš virtualaus asmens;

- bendravimo interaktyvumu; 
- paslaugu ịvairove ir kompleksiškumu (ịvairiais pagrindinių ir papildomų paslaugų paketais);

- paprastumu, bet vengiant banalumo ir nuobodumo.

Viena pagrindinių virtualaus asmens savybių yra vientisumas, kurio mastą galima apibūdinti kaip tam tikrų socialinės sistemos elementų (individualių ir kolektyviniu narių) tarpusavio interesų suderinamumo lygit (Cvilikas et al. 2007: 51). Veikiančioms virtualių asmenų institucijoms apibrěžti nepakanka vien atskirų asmenų bendroje terpejje fiksavimo, virtualaus asmens veiklos vientisumas užtikrinamas elektroniniais tarpusavio ryšiais, jų palaikymu, valdymu ir plètra.

Nepriklausomai nuo to, ar tai fizinis ar juridinis asmuo, virtualumo išraiškos priemonès bruožai gali turèti realų arba tik įsivaizduojamą pagrindą. Pirmiausia, kaip asmuo pateikiamas visuomeneje, tam tikroje veikloje ar kokiais ypatingais atvejais priklauso nuo asmens atliekamo vaidmens, vykdomų funkcijų ir galiausiai siekiamų tikslų.

Asmenys, kurių vaidmuo visuomenëje ir ekonomikoje bei jų strateginiai tikslai iš esmès skiriasi, gali būti suskirstyti ị: atstovaujančius tik sau (kūrybos, meno, individualiai paslaugas teikiantys, siekiantys karjeros ar kitų tikslų, saviraiškos ar kitus interesus tenkinantys ir t. t.); atstovaujančius sau ir kartu tam tikroms organizacijoms (mokslo, švietimo, kultūros, partijų, religinių bendrovių, kitų viešųjų, verslo ir t. t. organizacijų vadovai, atstovai, igaliotiniai ir darbuotojai) ir atstovaujantys tik tam tikroms organizacijoms ar net visuomenès sluoksnių ar grupių interesams. Virtualaus asmens vidaus ir išoriniai santykiai (ryšiai su aplinka) yra veiklos ir egzistavimo pagrindas (Korsakiene 2006: 238), nes pagrindinis jo privalumas - operatyvus ir interaktyvus žinių, patirties bei kompetencijos pasidalijimas.

Organizacijų viduje veikiantys virtualūs asmenys ar savarankiškai veikiančių virtualių asmenų, kuriuos vienija bendras tikslas ar interesai, junginys gali sudaryti bendrus aiškius bei susijusius organizacinius vienetus. Galimos kitos laikinos savanoriškos kelių, kaip ịprasta, nepriklausomų partnerių bendravimo formos, kurios leidžia tobulinti veiklą ir užtikrinti didelę naudą klientams ar visuomenei.

Virtualaus asmens objektais gali būti:

- objektai, kurių pripažinimas priklauso nuo jiems ar jų pačių sukurto ir palaikomo įvaizdžio. Šiai kategorijai galima priskirti asmenybes (politikos, laidų vedejus, visuomeninių organizacijų lyderius ar atstovus, socialines grupes (studentus, moksleivius, mokslininkus, kariškius), tam tikras institucijas (partijas, judejimus, bendruomenes, radijo - telekomunikacines laidas ir renginius). Šie objektai iš esmès yra nekomercinio tipo asmenybės ar organizacijos. Šių objektų veiklos tikslas - galimybè turèti ịtaką visuomenès nuotaikoms;

- objektai, kurių suvokimas ir pripažinimas priklauso tiek nuo pačių susikurto ịvaizdžio, tiek nuo komerci- nės situacijos. Tai tiktų meno ir kultūros atstovams, architektams, dizaineriams, modeliuotojams, manekenėms ir kitiems išskirtinių savybių turintiems asmenims;

- objektai, kurių pripažinimas vienodai priklauso tiek nuo turimo ịvaizdžio, tiek nuo pagaminto produkto ar suteiktos paslaugos kokybės. Prie tokių objektų priskiriami stambių nacionalinių ir tarptautinių kompanijų vadovai ir igalioti asmenys, taip pat ir smulkesnių imonių vadovai ir savininkai, jei jų veikla priklauso ne tik nuo to, ką jie parduoda, bet ir nuo to, kaip jie tai daro. Šių objektų veiklos tikslas - didinti pardavimo apimtị, kartu kuriant teigiamą ìvaizdị, tausojant aplinką ir išteklius bei gerinant produkcijos kokybę;

- objektai, kuriems visuomenės pripažinimas ir ịvaizdžio pokyčiai nèra aktualūs, tiesiogiai nesietini su veiklos sèkme. Dažniausiai tai smulkūs paslaugų teikejai ir prekeiviai, siauros srities mokslininkai ir specialistai. Jų vaidmuo rinkoje tiesiogiai priklauso nuo siūlomos paslaugos ar produkcijos kokybės, nes patys savo veiklos neorganizuoja. Šios kategorijos objektų skaičius plètojantis ekonomikai mažèja, o sąstingiu metu dideja.

Kad virtualus asmuo būtų geriau suvokiamas ir pripažintas virtualioje erdveje, jis turi turèti tam tikrų nekintamų ar lètai kintamų bruožų. Šie charakteringi bruožai gali turèti tam tikrų požymių, kurie leistų asmenị priskirti tam tiktai veiklai, profesijai ar socialinei grupei. Nors šie požymiai gali būti skirtingai suvokiami, tačiau jie visuomenei, partneriams ir klientams padeda lengviau susirasti ir bendrauti virtualioje erdvèje. Virtualaus asmens bendravimo reikalavimai turi būti aiškiai apibrěžti ir priimti bendru sutarimu. Juo tikslesnis ir konkretesnis įvaizdis, tuo didesnè tikimybė, kad jis bus tinkamas tik siauresnèms vartotojų grupèms ir tuo pat metu gali sukelti priešišką kitų grupių vartotojų reakciją. Siekiant išlaikyti didesnès ir ịvairesnių interesų auditorijos dèmesit, sudaromas neutralesnis ịvaizdis. Bet neprivaloma turèti neišraiškingo, neapibrèžto arba betikslio įvaizdžio. Universalesnis įvaizdis yra neutralesnis, jis leidžia jau kelioms gretimoms socialinėms grupèms palaikyti gerus tarpusavio santykius. Todèl galima platesnè pažiūrų įvairovè, nebūtinas didelis lojalumo asmeniui ar jo veiklai lygis. Jeigu toks įvaizdis kam nors ir nesukelia teigiamų emocijų, svarbu, kad nesukeltų neigiamo nusistatymo. Tačiau susiduriama su stereotipų egzistavimo problema. Anksčiau susiformavęs stereotipas veikia žmogaus apsisprendimą ir, objektyvaus stebėtojo nuomone, šis procesas neturi jokios logikos. Stereotipas yra konkretesnis už tam tikrų nusistovèjusių poreikių ar interesų struktūrą. Tai visiškai apibrèžtas matomasis, girdimasis, jaučiamasis, ̨̇sivaizduojamasis nusistatymas - kliento santykis su savimi, informacijos kanalais, remiamais objektais. Stereotipai priklauso minčių, jausmų pasauliui. Tai yra idealiosios sferos dalis, kuri turi 
didžiulę jègą, veikiančią realybę. Norint efektyviai panaudoti atskirų socialiniu grupių psichologinius ypatumus ir pritraukimo galimybes, būtina išsiaiškinti ir atsižvelgti i kai kurias charakteristikas. Pavyzdžiui, jaunimas linkęs ị aktyvų gyvenimo būdą, verslininkams svarbus patikimumas, kariškiai orientuojasi ị stabilumą ir t. t.

Pasyvūs veiksmai aplinkoje ir savo veiklos abejingumo demonstravimo pasekmès gali būti pražūtingos. Konkurencineje kovoje labai svarbu veiksmingai išnaudoti visus savo ir savo veiklos išskirtinumus bei privalumus. Virtualaus asmens priemimas ir suvokimas priklauso nuo jo aktyvumo, elgesio ir santykių visuomenèje ar tam tikroje rinkoje, nuo jo veiklos viešumo, vaizdumo ir akivaizdumo. Pripažinimas ir kartu geras virtualaus asmens vardas yra labai svarbūs pritraukiant visuomenès bei vartotojų dèmesị. Augant pasiūlai, gerèjant prekių ir paslaugų kokybei, kylant pragyvenimo lygiui vis daugiau vartotojų renkasi gerai žinomų virtualių asmenų produkciją, atsižvelgia ne tik ị paties produkto savybes, bet ir ị ji gaminusio ar parduodančio reputaciją.

Virtualaus asmens sąrangą sudaro tokie elementai, kaip iranga ir fizinès priemonès, telekomunikacinis procesas, jam reikalingos ir tam tikros žinios bei ištekliai. Paslaugu teikimo sistemą, kaip ir patị virtualų asmeni, reikètų suskirstyti ị dvi pagrindines zonas (Vengrienè 2006): kontaktinę ir tarnybinę. Kontaktinè zona laikoma klientams matoma veiklos dalis, kurioje ir vykdomos operacijos dalyvaujant arba stebint klientui. Šioje paslaugos teikimo sistemos dalyje klientas paprastai tiesiogiai bendrauja su personalu, o telekomunikacinių paslaugų atveju sąveika vyksta su priemonèmis ar iranga. Reikia pažymèti, kad tobulèjant informacinèms technologijoms, ši tendencija bus dar akivaizdesnè. Tarnybiné zona (vidinis paslaugų teikimo posistemis) yra klientui nematoma, ją sudaro personalas, informacinès technologijos ir telekomunikacinės priemonès bei procesai, kurie palaiko kontaktinę zoną bei ten vykstančius procesus tarp kliento ir paslaugas teikiančio asmens (1 pav.).

Galima išskirti šias virtualaus asmens struktūros dalis:

- asmens keliamus tikslus ir siekius (šeimą, poilsį, madą, karjerą, pomėgius ir kt.), viziją ir misiją, strategiją ir taktines priemones bei joms skiriamus išteklius;

- vykdomą veiklą, palaikomus vidinius ir išorinius ryšius bei vykdomas operacijas;

- asmens bruožus ir savybes, nustatytas pagal jo priklausomybę psichologiniam tipui, veiklos sritị ir mastą, kitus vidinius ir išorinius ryšius;

- vidinius veiksnius, elementus ir atributiką: veiklos politiką, bendravimo kultūrą, autoritetingus institucijos vadovus, komandą ar šeimą, istoriją, išvaizdą, pasirinktą stilių, emblemą;

- santykius su išorine aplinka: aktyvią visuomeninę veiklą, reportažus, viešas kalbas, santykius su partneriais, investuotojais, akcininkais ir vartotojais, viešiems projektams skiriamus išteklius ir dalyvavimą

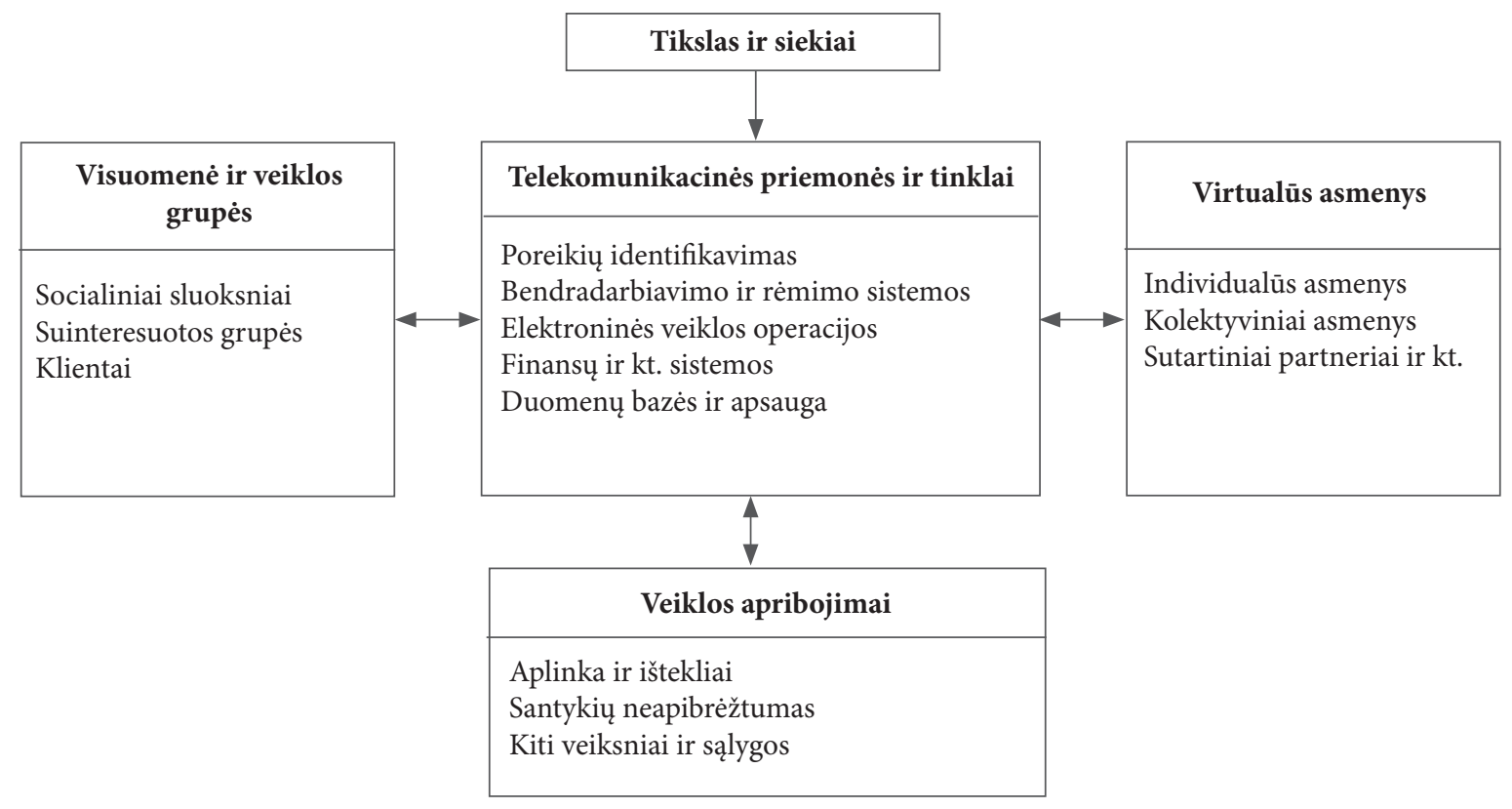

1 pav. Virtualaus asmens struktūrinių elementų sąveika

Fig. 1. Interaction of structural elements of a virtual person 
visuomeninejje veikloje, palankius nepriklausomų informacijos priemonių veiksmus, atsargius konkurentų veiksmus;

- naudojamas viešoje veikloje rinkodaros ir jos elektroninės komunikacijos priemones: elektroninị ryšĭ, tinklalapị ir registraciją paieškos sistemose bei kitose duomenų bazèse, veiksmingą reklamą, kitas veiklą palaikančias ir skatinančias priemones, svarbiausių vertybių, gyvenimo būdo, gyvenimo ar veiklos vietos pasirinkimą, rinkodaros lankstumą, prisitaikymą prie visuomenès ir rinkos pokyčių;

- naudojamus materialiuosius, žmogiškuosius, finansinius ir kitus išteklius.

Telekomunikacinių paslaugų teikimo procesas gali būti igyvendinamas naudojant įvairius virtualių asmenų, teikiančius ir naudojančius šias paslaugas, komponentus. Būtina pagrịsti paslaugas teikiančių ir jas naudojančių pavienių ar susietų ị organizacijas virtualių asmenų organizacinę struktūrą. Reikètų išskirti pagrindinius posistemius (Vengrienė 2006): veiklą ir operacijas, žmogiškuosius ir kitus išteklius bei rinkodarą, kurie sudaro svarbias prielaidas virtualių asmenų savybėms atsiskleisti ir veiklai plètoti.

\section{Virtualaus asmens veiklos plètros galimybès}

Virtualių asmenų veikla gali būti pagrịsta tradicinėmis vertybèmis ir principais, plačiau taikant informacines technologijas. Veikla ir operacijos glaudžiai susijusios su telekomunikaciniu paslaugu teikimo sistema, rinkodara, žmogiškaisiais ir kitais ištekliais, finansiniais sprendimais. Virtualaus asmens bendravimo, mokymo ir mokymosi galimybès gana plačios. Informacinèje, pagrịstoje žiniomis, visuomenèje svarbiausiais tampa nebe mokomi dalykai, o besimokančiųjų gebejjimai bendrauti ir tęsti mokymąsi visą gyvenimą (Lobanova 2009; Paliulis et al. 2007). Jų aplinka ir rinka motyvuoja tai daryti. Nuotolinio ir savarankiško mokymosi plètra, sudarydama visą gyvenimą trunkančio mokymosi prielaidas, padeda gerinti asmenų kompetencijas, prisitaikyti prie kintančių visuomenès gyvenimo sąlygų ir rinkos poveikio.

Per ryšius su rinkos dalyviais ir jų valdymo sistemą sudaromos veiklos prielaidos ir paslaugų teikimo galimybès. Kad veikla būtų tikslinga ar tenkintų tam tikrus interesus, ji turi remtis rinkos tyrimais ir prognozėmis, technologiniais procesais, patirties kaupimu ir pasidalijimu, bendravimu ir sandorių sudarymu, įsipareigojimų vykdymu ir t. t.

Sèkmingą virtualaus asmens veiklą erdvèje, be fizinių ribų, veikia gebejjimas kryptingai naudoti esminius, unikalius gebejimus ir sunkiai imituojamus kitus išteklius, kurie skirstomi i materialụji ir nematerialųji turtą. Tinkamas ju derinimas veikia gebejimus bei suvokiamas kaip stiprybių ir silpnybių rinkinys (Gudonavičius, Savanevičienè 2008: 362), kuris gali lemti išskirtinių bruožų (nematerialaus turto pavidalu) naudojimo galimybes perspektyvoje.
Sprendimų prièmėjas apibrèžiamas kaip virtualus asmuo, vykdantis nuoseklius svarstymo procesus, siekiantis parinkti sau ypač veiksmingą sprendimą. Paneigiamas dažnai deklaruojamas racionalus sprendimų prièmimo būdo efektyvumas, nes aplinkosaugos, organizacinių, situacinių, grupių dinamikos ir individualių apribojimų derinimas susilpnina racionalių modelių teikiamą naudą (Hale et al. 2006: 302-305). Todèl virtualiems individualiems ir kolektyviniams asmenims aprašomieji sprendimų priėmimo modeliai leidžia praleisti kai kuriuos sprendimų prièmimo etapus, taip pat lygiagrečiai arba nuoseklios iteracijos būdu įterpti kitus sprendimų prièmejjui reikalingus etapus. Tačiau virtualiems individualiems asmenims labiau tinka vadinamasis natūralistinis sprendimų priemimo (intuityvus) modelis, nes iš viso galima apsieiti be gana sudètingu sprendimų prièmimo prielaidų. Šis modelis leidžia vertinti keletą alternatyvų, jas lyginti ir atmesti nepriimtinas. Alternatyvų vertinimas grindžiamas jų ir konkrečios situacijos bei sprendimų prièmejjo vertybių suderinamumu.

Tai gali būti ir bendri kultūrinių vertybių veikiami standartai, ir kiti protingumu grịsti principai. Prie bendrų suvokimo charakteristikų galima priskirti reakciją i tam tikrą spalvą, orientaciją i pranešimą, padedantị suvokti elektroninio kanalo galimybes, pripratimo efektą ir pan.

Bendravimas iš esmès pagrịstas bendrais operatyvių ryšių kanalų principais, bet tiesiog virtualioje erdveje igyja svaresnị vaidmenį dèl nuotolinio dalyvio būvio. Dalyvavimas virtualioje erdvejje tampa neišvengiamu fizinio ar juridinio asmens bruožu, todèl jie turi išnaudoti teikiamas interneto galimybes. Asmeniniuose individualiuose tinklalapiuose, neretai ir meno, mokslo, visuomenès veikejjų ir kitų žmonių, pasakojama apie save, žymius žmones, dėstomi pomėgiai, pateikiama kūryba. Šiuose tinklalapiuose dominuoja nuotraukos, paveikslèliai, teksto gana nedaug, vyrauja šnekamoji kalba. Jie turi turèti tikslinę paskirtị, kitaip neduos jokios naudos. Tikslinè tinklalapio paskirtis lemia tinklalapio tipo parinkimą. Pirmiausia tikslinè tinklalapio paskirtis yra informacinè ir reklaminè. Interneto vartotojai gali juose rasti įvairiausios informacijos apie asmenį, jo veiklą, pasiektus rezultatus (renkant kolekcijas, kaupiant tam tikros srities informaciją iš meno, mokslo ir kitų sričių), viešus interesus, siūlomą pagalbą ir paslaugas, kitos įdomios medžiagos bei nuorodas patekti i tam tikrus puslapius. Virtualaus asmens statusas padeda naudotis tarptautinio darbo pasidalijimo privalumais ir gauti naudos. Tai yra vienas iš jų pranašumų palyginti su ịprastomis klasikinèmis darbo paieškos ir ìdarbinimo schemomis. Tai leidžia praplèsti savo galimybes neribojantis nei regionu, nei išlaidomis ryšiams užmegzti ir palaikyti, nei kitais ištekliais. Tačiau negalima pervertinti naujų technologijų vaidmens informuojant klientą, nes technologinès ryšių priemonès standartizuotos ir nelieka išskirtinio patrauklumo. Todèl sukurtas įvaizdis ir reputacija, bendravimo kultūra, operatyvumas gali išlikti tomis 
vertybėmis, kurios trauktų visuomenę, partnerị ar klientą ir papildomai veiktų renkantis vieną ar kitą bendravimo ir išraiškos priemonę. Todèl kyla virtualių asmenų pozicionavimo problema: jų vietos rinkoje ir kitų konkurentų atžvilgiu, akcentuojant tiesioginio bendravimo ir žmogiškojo veiksnio ittaką, pasirenkant alternatyvas ir strategijas ir kartu priimant sprendimus.

Kiekvienas virtualus organizacijos narys, vadovas ar kitas, sudarantis komandą, asmuo turi identifikuoti kitus realius ir virtualius narius, kurie dirba panašų darbą ar kurių veikla susijusi. Profesiniai ir išoriniai ryšiai laikomi labai svarbiais. Norèdamas pasiekti gerų veiklos rezultatų, kiekvienas individas turi suvokti savo vertę ir vertinti kiekvieną kitą komandos narị pagal jo indèli organizacijoje (Markovic 2008). Vienas iš esminių virtualaus asmens veiklos principų - veikti išvien kaip komanda, o ne kaip atskirų individų grupé. Kiekviena komanda ar visa virtuali organizacija turi turèti tikslą. Tai gali būti komandos iškeltas uždavinys ar gautas iš tam tikrų aukštesnio lygmens virtualios organizacijos sluoksnių. Turi vyrauti atmosfera, leidžianti realizuoti gebejjimus ir iniciatyvą, pripažinti bei išreikšti individualius kiekvieno nario jausmus.

Ne mažiau svarbūs yra dinaminiai bruožai, labiau priklausantys nuo išorinių veiksnių ir sąlygų. Tai praplečia virtualaus asmens galimybes, kai nekintant vidiniams bruožams lanksčiai prisiderinama prie aplinkos, o kartu prie visuomenès ir klientų lūkesčių. Tai individualizuotos savybès, kurios virtualioje erdvẻje gali turèti gana menką ryši. Todèl plečiant virtualaus asmens galimybes ypač svarbu:

- laikytis moralès normų, nes pagal tai visuomenè bando spręsti apie virtualaus asmens ir jo veiklos patikimumą;

- naudojama aukštos kokybės atributika: emblema, firminiai blankai, korespondencija, reklaminiai bukletai, skelbimai, iškabos;

- palankus požiūris ị visuomenę, partnerị, klientą;

- lankstumas sprendžiant kilusias problemas bei reaguojant ị užklausas, komentarus, nusiskundimus;

- geras visuomenès informavimas apie veiklą, jos pasiekimus. Dalyvavimas parodose, mugėse, labdaros renginiuose. Asmens ar organizacijos atstovo kalbos žiniasklaidoje, teigiami straipsniai spaudoje;

- tiksli, patraukli, patikima ir laiku pateikta informacija;

- saviraiška, atvira ir sąžininga konkurencija;

- kvalifikuota ir ekologiška veikla;

- visapusis operatyvus ryšys su aplinka.

Virtualioje sistemoje tam tikri darbai gali būti dubliuojami (Turban et al. 2006). Tai gali gerinti galutinę veiklos kokybę bei turèti teigiamą ittaką, kai susiduriama su netikètomis kliūtimis. Individualūs komandų nariai turi būti skatinami palaikyti savo asmeninius ryšius, nebūtinai susijusius su dabartiniu komandos tikslu.

Nepriklausomai nuo pavienių ar susietų ị organizacijas virtualių asmenų statuso jie gali naudotis šiomis organizacinèmis techninemis priemonemis (Zheng et al. 2009): vieno lygio su sudètingais horizontaliaisiais ryšiais; iveikti geografinius, laiko ir finansinius apribojimus; palaikyti daugialypius ryšius ir igyvendinti kelis projektus vienu metu; lanksčiai naudoti žmogiškuosius išteklius; operatyviau spręsti sudètines problemas; suteikti galimybę geriau vykdyti savo funkcijas; didinti koordinavimo galimybes; mažinti vertikaliụjų linijinių ryšiu įtaką; geriau prisitaikyti prie individų, tam tikrų grupių, verslo ir visuomenès interesų.

Virtualaus asmens veikla gali būti pagrịsta laikinomis funkcinemis reikmėmis arba ịprasto strateginio tikslo siekimu, neturi jokių formalių fizinių ribų. Virtualūs asmenys organizacijoje gali būti siejami vyraujančiais horizontaliaisiais ryšiais, grindžiamais sutartiniais įsipareigojimais.

Virtualus asmuo privalo būti dar lankstesnis, geriau prisitaikyti prie naujų pokyčių, lanksčiau orientuotis į naujas galimybes ir išvengti atsirandančių grèsmių. Virtualaus asmens veikimo sistema, turinti tam tikrą struktūrą, turi būti patikima ir pajejgi susidoroti su visais jai keliamais reikalavimais bei nenumatytomis aplinkybėmis. Joje turètų būti numatytos duomenų atnaujinimo procedūros, kad informacija apie ryšius nebūtų prarasta. Sistema turètų greitai reaguoti net ir ypatingomis sąlygomis, nes kitaip ji taps nebepatikima ir neveiksminga. Norint išvengti netiketumų ir krizinès situacijos, būtina sujungti bei panaudoti visas veiklos grižtamojo ryšio grandis: struktūrizuotas ir iš anksto numatytas priemones, taip pat prisitaikantị nekontroliuojamą grị̌̌tamąji ryšį. Struktūrizuotas ir suderintas grịžtamasis ryšys naudojamas tvarkai ịvesti ir palaikyti ilgalaikę pagrindinę veikimo krypti. Jei atsiranda ir pradeda reikštis nelauktas aplinkos poveikis, galima laiku reaguoti kaip i naujai besiformuojančias tendencijas. Prisitaikantis grịžtamasis ryšys lemia trumpo laikotarpio planų ir užduočių patikslinimą. Ryšių ir veiklos valdymo sistemos turi atskirti, kurios sąlygos pasikeite ir kuriose struktūros dalyse būtini reikšmingesni pokyčiai, nes nedideli pertvarkymai yra mažai naudingi ir veiksmingi. Prisitaikantis grižtamasis ryšys dažnai yra atsakas ị realius, bet nelauktus nukrypimas nuo planų ir gali keisti net pagrindines veiklos kryptis: ir strategiją, ir taktinius operatyvinius sprendimus.

Pagrindinis strateginis virtualių asmenų privalumas greičiau reaguojama viso veiklos ciklo mastu - nuo finansinių išteklių paieškos iki užsakymo ir jo įvykdymo - realiuoju laiku ir daug veiksmingiau nei ipprastose organizacijose. Kliento poreikiai atsiranda jam sudarant ir siūlant naujų galimybių, nes pati virtualaus asmens kūrimo filosofija yra ne problemų sprendimas (finansinių išteklių, laiko ir energijos naudojimas savo silpnybėms ịveikti), bet galimybių paieška ir stipriųjų savybių ugdymas. 


\section{Išvados}

1. Virtualiais asmenimis gali būti asmenys ar institucijos, bendraujančios virtualioje erdveje (privatūs asmenys, visuomenès, socialinių grupių ir kt. atstovai, paslaugų teikejai, tarpininkai, vartotojai, administruojančios ir kitos ìstaigos).

2. Virtualius asmenis ar savarankiškai veikiančius virtualių asmenų junginius vienija bendras tikslas ar interesai, jie renkasi bendravimo formas ir priemones, kurios leidžia tobulinti veiklą ir užtikrinti didesnę naudą klientams ar visuomenei.

3. Vertinant taikomus virtualaus asmens modelius buvo atsižvelgta ị lojalumo asmeniui ir jo atpažinimo lygị, veiklos atvaizdavimo kokybę, atstovaujamos institucijos ženklo identiškumą, elektroninių išraiškos priemonių išskirtinumą, masiškumą, prieinamumą, interaktyvumą ir kitus kriterijus.

4. Virtualaus asmens poreikiai atsiranda jam sudarant ir siūlant naujų galimybių, nes pati virtualaus asmens kūrimo filosofija yra ne problemų sprendimas, bet galimybiu paieška ir stipriųjų savybių ugdymas.

5. Asmenims, naudojant nuotolines ryšio palaikymo priemones, jie nebūtinai egzistuoja konkrečioje fizinèje erdvèje. Virtualus asmuo gali būti daug lankstesnis nei fizinis, geriau prisitaikęs prie naujų išorinių sąlygų, orientuotas į naujas galimybes ir galintis geriau išvengti atsirandančių grèsmių.

6. Didžiausią vertę ir naudą virtualiems asmenims teikiantys sprendimo modeliai yra sudètingesni nei fiziniai, nes sujungiant ịvairaus lygio elementus ypač daug dèmesio skiriama strateginiams klausimams: trukmei, tikslui, kokybei, gaunamai tiesioginei ir netiesioginiai naudai. Klientų tipai vaidina mažesnị vaidmeni, bet tam tikri jų požymiai: amžius, pajamų lygis, socialiné padetis ir kiti yra išskirtiniai. Čia paslaugos teikimo procesui skiriama ypač daug dèmesio, nes per bendravimą jis gali veikti tikètiną rezultatą.

7. Dalyvavimas virtualioje erdvèje tampa neišvengiamu sèkmingos veiklos bruožu, todèl virtualūs asmenys gali geriau išnaudoti interneto galimybes. Asmenų kuriami tinklalapiai turi turèti tikslinę paskirtị, kitaip jie neduos jokios naudos. Tikslinè tinklalapio paskirtis lemia tinklalapio tipo parinkimą. Pirmiausia tikslinè tinklalapio paskirtis yra informacinè ir reklaminè.

8. Informacines technologijas leidžia taupyti administracines, transporto ir kitas išlaidas. Mažèja išankstinè teigiamų ir neigiamų stereotipų susidarymo įtaka.
9. Sprendžiant konkrečią virtualaus asmens įvaizdžio kūrimo užduotị galima iš anksto ịvertinti pagrindinius visuomenès narių stereotipus, būtinas poveikio ir išraiškos priemones jų suvokimui pakeisti.

10. Tinkamai parinkę ir panaudoje elektronines išraiškos ir kitas informavimo priemones bei jų galimybes, virtualūs asmenys gali plačiau, išsamiau ir sistemingiau informuoti apie save, savo galimybes, siekius ir teikiamą naudą kitiems, išvengti didelių išlaidų ir šiurkščių klaidų.

\section{Literatūra}

Cvilikas, A.; Gatautis, R.; Karpavičius, T. 2007 Application of systemic management conception to organization's management decisions structuring, Inzinerine Ekonomika - Engineering Economics (4): 44-52.

Gudonavičius, L.; Savanevičienè, A. 2008. Vidinès ir išorinès aplinkos ịtaka priimant strateginius sprendimus, Ekonomika ir vadyba [Economics and Management] 13: 362-367.

Hale, J. E.; Hale, D. P.; Dulek, R. E. 2006. Decision processes during crisis response: an exploratory investigation, Journal of Managerial Issues 18(3): 301-320.

Korsakienè, R. 2006. Organizacinių pokyčių valdymas: teoriniai ir praktiniai aspektai, Verslas: teorija ir praktika [Business: Theory and Practice] 7(4): 237-242.

Korsakienè, R.; Tvaronavičius, V.; Tvaronavičienė, M. 2006. Incorporating innovations into organizations functioning: virtual versus traditional firm, Verslas: teorija ir praktika [Business: Theory and Practice] 7(1): 27-31.

Langvinienè, N.; Vengriené, B. 2005. Paslaugų teorija ir praktika. Kaunas: Technologija. 365 p.

Lobanova, L. 2009. Žmogiškųjų išteklių vadybos vertė žiniomis grindžiamoje visuomeneje, Verslas: teorija ir praktika $[\mathrm{Bu}-$ siness: Theory and Practice] 10(3): 233-246. doi:10.3846/1648-0627.2009.10.233-246

Markevičius, J. 2005. Personnel Management of Virtual Organization: Summary of Doctoral Dissertation. Vilnius: Technika. 25 p.

Markovic, M. R. 2008. Managing the organizational change and culture in the age of globalization, Journal of Business Economics and Management 9(1): 3-11. doi:10.3846/1611-1699.2008.9.3-11

Paliulis, N.; Pabedinskaitè, A.; Šablinskas, L. 2007. Elektroninis verslas: raida ir modeliai. Vilnius: Technika. 236 p. doi:10.3846/858-S

Saabeel, W., et al. 2005. A model of virtual organization: a structure and process perspective, Electronic Journal of Organizational Virtualness 4(1).

Sodžiutè, L.; Sūdžius, V. 2006. Elektroninis verslas: pardavimas ir finansines priemones [E-commerce: Sales and Financial instruments]: monografija. Vilnius: Kronta. 295 p. 
Stankevičienè, J.; Dudènienè, V. 2008. Virtuali organizacija - kuo ji ypatinga? Ekonomika ir vadyba: aktualijos ir perspektyvos [Economy and Management: Current Issues and Perspectives] 360-365.

Sūdžius, V. 2007. Apsisprendimas naudotis finansinèmis paslaugomis mažmenineje rinkoje ypatumai, Verslas: teorija ir praktika [Business: Theory and Practice] 8(2): 107-111.

Turban, E.; King, D.; Viehland, D.; Lee, J. 2006. Electronic Commerce 2006: A Managerial Perspective. New Jersey: Pearson Prentice Hall, Inc, Upper Saddle River. 792 p.
Vengrienė, B. 2006. Paslaugu vadyba. Vilnius: Vilniaus universiteto leidykla. 272 p.

Zheng, W., et al. 2009. Linking organizational culture, structure, strategy and organizational effectiveness. Mediating role of knowledge management, Journal of Business Research. Prieiga per internetą: <www emeraldinsight.com $>$.

Artūras STEPANOVAS. PhD, works as lecturer at Vilnius Gediminas Technical University, Department of Finance Engineering. Research interests: engineering economics, project management and finance markets.

Vytautas SŪDŽIUS. PhD, works as Associate Professor at Vilnius Gediminas Technical University, Department of Finance Engineering. Research interests: development of small and medium business, marketing and finance. 